\title{
The Relationship of Indonesian Language Learning with the Environment
}

\author{
Mulia Resti/190116106 \\ Muliaresti04@gmail.com
}

Environment is a component that is influential in the implementation of activities to learn to teach. The environment can also support the course of teaching and learning activities in schools. Schools with a clean environment will make students learn comfortably and vice versa. Environmental problems are not a new problem in Indonesia. One of the efforts to overcome environmental problems is by instilling the importance of the environment in the younger generation from an early age. Instilling a sense of responsibility and awareness of protecting the environment can be included in environmental materials in Indonesian language learning .

According to Ramadhan, Sukma, and Indriani (2019), around the world, many methods have been applied to solve environmental problems, such as government policies to attract people from nature-loving movements and strengthening government regulations. However, this method is not effective enough to reduce environmental problems. It takes the development of individuals who are aware and responsible for the environment to overcome this so that environmental problems can be handled properly. This can be realized through education. Nkwetisma (in Ramadan, soul, and Indriani, 2019) stated that environmental education is a joint effort that is consciously organized to teach or attract human attention on how the natural environment functions and how man is able to manage and protect the nature of it.

According to Obasaro, Oyinloye, and Ilensami (in Ramadhan, et al 2019), students need to have experience and take initiative in relation to pressing requirements in the field of global and societal challenges. According to Bregman B,G (in Ramadhan et al, 2019) to overcome this problem, teachers play an important role in teaching environmental education . For instance, in learning language Indonesia, the teacher can provide environmental material to students so that students can better understand a concrete example that can be encountered in the surrounding neighborhood, or in the presence of environmental material in Indonesian language learning easier for students to pour the idea in writing, so that the writing skills even better. Then the material environment in Indonesian language learning in school is very important in the learning Languages Indonesia.

Angin, Ramadhan, and Agustina (2015) said that using environmental materials made students more sensitive to their environment because they could present their observations. Attitude and high motivation to learn the student is expected to assist in the achievement of the results of learning are maximized. Zulhafizh, Atmazaki, and Ramadhan (2013) said that increasing student attitudes and motivation in learning activities is expected so that student 
learning outcomes also increase. Efforts to determine the level of the role of attitudes and learning motivation on learning outcomes, especially in Indonesian language lessons, it is necessary to observe and analyze attitudes and behavior 
the learning motivation. This can assist teachers in formulating various strategies that should be planned in developing teaching and learning activities, especially in Indonesian language lessons .

According to Jacobs GM M and Cates K (in Ramadhan et al, 2019), the purpose of environmental education is to make students participate in protecting the environment and make students participate in protecting the environment. According to Kollmus A and Agymen J, Schultz P W, Shriver C, Tabanico J J, and Kazian A M, Xehua Z, and Cokcaliskan $\mathrm{H}$ and Celik O (in Ramadhan et al, 2019), in order for students to participate in protecting the environment, it is important to link environmental knowledge, awareness of the environment and changes in behavior towards the environment. Individuals should be encouraged to not look at the environment as something to be exploited for their goals, but as an asset of value that is worthy of being protected for the survival of living humans.

According to Amelia, Sukma , and Asma (2015) students who develop writing skills from an early age acquire valuable tools for learning, communication, self-expression and helping them succeed in school and society. Students who have good writing skills can participate in increasing public awareness of the environment, one of which is by producing persuasive texts which essentially invite people to care about the environment. With this, it is hoped that it can change people's perceptions of the environment, and people are more concerned about environmental cleanliness .

According to Sukma, Ramadhan, and Indriyani (2020) learning about the environment has a positive impact on the knowledge, values and attitudes of students in relation to the environment. Environmental education can help students rethink the relationship between humans and their environment, begin to understand the environment, be aware of various environmental problems and think of solutions to these problems .

Educational environment can be applied to the entire student with age are different.

Based on the questionnaire that the author distributed regarding "The Relationship of Indonesian Language Learning with the Environment" to Padang State University students in semester 5, Andalas University students in semester 5, students at Putra Indonesia University YPTK Padang in semester 5, Stikes Binalita Sudama Medan in semester 5, and undergraduate Nursing students in semester 5 Of the total 34 respondents who participated in filling out the questionnaire, 26 respondents were more dominant female and 8 male respondents were $76.5 \%$ female and $23.5 \%$ male. The results of the percentage of questionnaire data that have been carried out through the google form can be seen as follows. The first statement , "Teachers play an important role in teaching environmental education" $32.4 \%$ strongly agree, $64.7 \%$ agree, $2.9 \%$ disagree, $0 \%$ disagree. The second statement, "Teachers are easier to exemplify learning material based on environmental material than scientific theory" $23.5 \%$ stated strongly agree, $67.6 \%$ agreed, $8.8 \%$ disagreed, $0 \%$ disagreed. The third statement " Environment is very important to students' understanding of the lessons they are studying" $41.2 \%$ strongly agree, $58.8 \%$ agree, $0 \%$ disagree, $0 \%$ disagree. The fourth statement, "The existence of environmental material in Indonesian language lessons makes it easier for students to express ideas in written form, so that their skills" 
writing will be even better" $35.3 \%$ stated strongly agree, $64.7 \%$ agreed, $0 \%$ disagreed, $0 \%$ disagreed. The fifth statement, "With the material environment in learning language Indonesia does not foster interest and enthusiasm the students in learning" $11.8 \%$ stated strongly agree, $50 \%$ stating agree, $20.6 \%$ stated disagree $17.6 \%$ stated not agree. The sixth statement, "The curriculum should include more material in the environment of learning language Indonesia at SMP" 17.6\% stated very agree, 76.5\% declared agreed, 5.9\% stated less agree, $0 \%$ stated not agree. Statement of the seventh, "Students who have knowledge of the environment in learning Indonesian to support the knowledge and skills to write, so writing skills will be good again" $20.6 \%$ stated very agree, $79.4 \%$ menyakan agree, $0 \%$ said less agree, $0 \%$ disagree. The eighth statement , "Students need to have experience in taking initiatives in connection with urgent requirements in the field of global and societal challenges" $17.6 \%$ strongly agree, $70.6 \%$ agree, $11.8 \%$ disagree, $0 \%$ disagree . The ninth statement, "The environment can directly or indirectly develop a mindset, act, behave physically and mentally healthy in everyday life" $41.2 \%$ strongly agree, $58.8 \%$ agree, $0 \%$ disagree, $0 \%$ disagree. Tenth statement, " Learning Indonesian can improve communication skills of participants students in the environmental community" $41.2 \%$ stated very agree, 58.8 $\%$ stating agree, $0 \%$ stated less agree, $0 \%$ stated not agree.

From the results of the questionnaire statements that have been distributed, the authors can conclude that environmental materials in language learning are very important. It is caused due to the material environment is more close relation with life everyday, especially students.

According to the author, public awareness, especially students who are respondents to the role of the environment and its benefits, is categorized as good. With this role and benefits of the environment can be easier for students and teachers in teaching and understanding the material environment with regard learning Indonesian. 


\section{REFERENCES}

Elfia Sukma. 2015. Improving Writing Skills with the PAKEM Model Through Techniques to Become a Junior Journalist in Elementary School. Journal of Science and Human Education . 8(1).

Ramadhan, S., Sukma., \& Indriyani, V. (2019). Environmental Education and Disaster Mitigation Throgh Langunge Learning. IOP Conference Series: Earth and Environmental Science, 314, pp14.

Obasoro C B, Oyinloye O A and Ilensami A A The importance of environmental education to secondary education Level in Akure South local government area, Ondo State Nigeria African Research Review 7(4) 298-360.

Bergman BG 2016 Assessing Impact of Locally Designed Environmental Education Projects on Students' Environmental Attitudes, Awareness, and Intantion to Act Environmental Education Research 22(4) 480-503.

Wind, Toras Berita Bayo, Ramadhan S., Agustina . (2015). Based Approach Contextual On Writing Ads In Class VIII SMP 2 Padangsidimpuan Sumatera Utara. Journal of Language, Literature, and Learning . 3(1);27-31.

Zulhafizh, Atmazaki, S., Ramadhan. (2013). Contribution of Students ' Attitudes and Learning Motivation to Indonesian Language Learning Outcomes . Literary Language and Learning . 1 (2).

Amelia, Rizki, Elfia Sukma, and Nur Asma. (2015). Learning to Write Experimental Reports with a Scientific Approach in Schools . Proceedings of the National Seminar on PGSD Department, Vol 1 (1).

Sukma, Elfia, Ramadhan, and V Indriyani. (2020). Integration of Environmental Education in Elementary Schools. PhysicIOP Conf. Series: Journal of Physic: Conf. Series 1481.

Syofiani, M., Zaim, S., Ramadhan, A., Agustina (2019). Skill Language Students Through the Use of Media Puzzle Cross: Creating classes are fun . Ta'dib , 21 (2); 87-89.

Sukma, E Ramadhan, S Indriyani, V. (2020). Integration Of Environmental Education In Elementary Schools. Journal of Physics: Conference Series . 1481(1):1-2. 